\title{
The Exemplary Ethical Leadership of King Moshoeshoe of Basotho of Lesotho in the Nineteenth Century Southern Africa
}

\author{
Khali Victor Mofuoa \\ Centre for Applied Philosophy and Public Ethics, Charles Sturt University, Australia \\ Email: khalimo25@gmail.com
}

Doi:10.5296/ jpag.v5i3.8129

URL: http://dx.doi.org/10.5296/ jpag.v5i3.8129

\begin{abstract}
There is no gainsaying in that nation-building requires bold, visionary, and above all, exemplary ethical leadership. King Moshoeshoe 1 of the Basotho of Lesotho standing as an exemplar of ethical leadership is abundantly supported both by his monumental achievements and by the ethical qualities of his organizational creative leadership. The purpose of this exemplar profile is to display his underappreciated record of individual moral responsibility for social science disciplines i.e. political management, political science, political philosophy, public administration, business administration, leadership studies, organizational theory etc. There is so much these disciplines can learn about the nature of ethical leadership and its relationship to public organizational effectiveness from Moshoeshoe's leadership philosophy, managerial style, organizational behavior and decisions in their quest for building harmonious and just societies worldwide.
\end{abstract}

Keywords: Basotho of Lesotho, Moshoeshoe and Mohlomi, ethical leadership, ethics and attributes of leadership, moral exemplar and organizational effectiveness 


\section{Introduction}

Writing in Exemplary Public Administrators: character and Leadership in Government, Cooper and Wrightpersuasively argue that a good society requires moral exemplars, that the number of moral exemplars is diminishing, and that it is incumbent upon us, as practitioners and academicians, to seek them out and to explain their worthiness and impact to students, lest we neglect the obligation to train new generations of public servants to understand their moral obligations (1992: 9-29, 81). In their chapter, Hart and Hart echoed Cooper and Wright sentiments, by stressing the importance in government of moral character, which at its core involves "the voluntary acceptance of the moral obligation to use power only in the service of the public interest" (1992: 89). They adopt a deontological perspective, although they assert, without attempting proof or argument, that "good character is positively related to organizational effectiveness (Hart and Hart: 1992, 83).

This paper is fashioned to encourage theory development relative to moral exemplars along the lines undertaken by Cooper and Wright (1992). They combined the Hart and Hart's (1992) typology of "moral conduct" with MacIntyre's (1984) conceptualization of virtue based on "practices," defined as " coherent and complex forms of cooperative activity organized around the pursuit of certain goods that are internal to these activities" (Cooper and Wright, 1992). In an endeavor to move in this direction, the paper will be structured as follows: First, some background on Moshoeshoe's beginnings, education and achievements are presented. Second, in some detail a recitation of the personal attributes, practices, and beliefs that defined the moral core of Moshoeshoe's leadership style, including his ethics and attributes of leadership are discussed. Third, in some detail Moshoeshoe's respected personal moral traits his leadership style are highlighted. Forth, moral shortcomings and prowess of Moshoeshoe's leadership style are presented. Fifth, Moshoeshoe's moral qualities contributions to his effectiveness as a leader are speculated. Sixth, by way of conclusion the seeming moral contradiction of Moshoeshoe as a moral exemplar who was both a champion of war and a champion of peace is highlighted.

\section{Moshoeshoe's Beginnings, Education and Achievements}

King Moshoeshoe 1 (hereafter Moshoeshoe), whose birth name was Lepoqo, was born in 1786 in the Eastern Highveld beyond the Drankensberg, now present-day Lesotho. His early childhood was a happy one, and as a young warrior without any moral problem with wars he had later in his life, he quickly gained reputation and was known as Letlama, the binder, after the way he would allegedly bind and subsequently subdue his enemy. After their circumcision class, his whole age group was called the Matlama, which means "the Binders." The Matlama were extremely loyal, and in war formed a single regiment under Lepoqo's command. One raid was so successful the he gained a new name - Moshoeshoe, which implies the swish of the razor. It was said that after this raid he returned with so many cattle that he had shaved the beard off the raided chief, Ramonaheng of the Bafokeng (Becker, 1969: 23-24; Sanders, 1975: 11-12). 
Early on, it seemed that Moshoeshoe was ambitious, and he sought the advice of a successful great chief and wise seer of the Caledon valley, Mohlomi of the Koena. He was seeking a way forward in his quest to become a chief, and not just a mere clan chieftain like his father. To this end, "Mohlomi's words were to have a profound effect on Moshoeshoe, highlighted by the horrors to come - "Go, rule by love, and look upon thy people as men and brothers" (Knight, 1994:59). Or as Fred Ellenberger records this same event, "One day thou wilt rule men: learn, then, to know them; and when thou judgest, let thy judgements be just.' Moshoeshoe never forgot these words, and throughout a long and famous life tried to act up to them" (Ellenberger, 1912:96).

Lesotho, under Moshoeshoe, attracted people from various parts of our sub-continent, who had fled from the devastation that came to be known as Lifaqane (wars of calamity), as King Shaka Zulu (hereafter Shaka) consolidated his Zulu kingdom through military conquests in present-day Kwazulu-Natal province of Republic of South Africa. While historians may give various explanations for these momentous events, there is a general agreement that the resulting wars shook the social foundations of many societies in southern Africa. The Lifaqane triggered a series of catastrophes that caused bloodshed, social and political disintegration and collapse of confidence in leadership. It was in this context that Moshoeshoe exercised his ethical leadership and founded Basotho as a nation in present-day Kingdom of Lesotho.

Moshoeshoe lived according to high moral standards, which made Lesotho to have all the hallmarks of a first-generation kingdom: its cohesion depended less on institutions than on the towering personality (or character) of its founder (Thompson, 1975: 212). According to Thompson (1975: 212), "Moshoeshoe possessed the charisma of a leader who had emerged in his people's darkest hour and steered them through unprecedented physical and moral disasters to a new plane of prosperity and self-confidence . . . Yet he remained a man of simple tastes: He retained the common touch, never demanding obsequious behaviour from anyone ... [and] [h] is reputation for justice and clemency was proverbial." Providing a glimpse of the aura of Moshoeshoe's personality, Arbousset said as related by Thompson (1975: 213-214): "Everywhere on the way, people flocked from numerous villages towards Moshoesh[oe], to hail him and present him with sacred reeds. Others, the better to celebrate his passage, brought him cattle as presents. In everything, this African prince showed tact that I greatly admired. His affability did not flag for an instant. Warmth, gaiety, nothing is lacking. He talks to everyone without distinction of age or rank. He even amuses himself with children as if he were one himself; and still more astonishing, his memory is so good he seems to know the name and the history of each of his subjects. You can imagine that, with such qualities, he is popular amongst them."

Through moral influence and prowess, Moshoeshoe built the Basotho nation in a situation as uncertain and insecure as the time of the Lifaqane. Against all odds, it seemed that Moshoeshoe's concern was to build and maintain a cohesive and united kingdom through making cultural plurality to be a binding value for the Basotho. To this end, he ruled by a system of alliances and tribute beyond his borders and consensus building within, which enabled him built loyalty and allegiance. In his management of public affairs, he furthered the 
tribal methods learnt from his youth in which "[h]e allowed his followers to appeal to the chief's court (Lekhotla) against his own decisions" (Thompson, 1975: 175). In this way, he was able to prove that diversity can be a binding attribute, in an environment in which it could otherwise be expected to be divisive. This seems a key principle of leadership for Moshoeshoe, which has its roots from his overarching values of peace and social justice.

Moshoeshoe preferred to rule his people by consensus, leading them subtly round to his way of thinking in the Pitso, the public gathering where events (and/or issues) of national importance were discussed (Knight, 1994: 54). His open-handed style of leadership thus enabled him to establish a kingdom, which was to be the envy of many (Knight, 1994: 90-92). Commenting on the distinctive virtuous qualities of King Moshoeshoe's rule, AzarialSekese who had known Moshoeshoe said as related by Thompson (1975:215): he disposed even-handed justice: he did not retaliate against people like Rakotsoana the cannibal chief who had wronged him; he gave sanctuary and aid to refugees; and he was not too proud to pay tribute to other rulers, such as King Shaka Zulu, for diplomatic advantage.

Even though the reigns of Moshoeshoe's leadership were held somewhat slightly, especially in comparison to his Zulu counterpart Shaka, he had a knack for effective leadership. His unusual way of leadership model thus challenged the growing cynicism at the time that viewed leaders as morally bankrupt and power-hungry mongers. This view had its genesis from Moshoeshoe's contemporaries, for example, Shaka who used sheer raw power and brutality to build Zulu Kingdom in the present-day Kwazulu-Natal province of Republic of South Africa. He seemed to have understood that leadership challenge ought to be in being able to recognize that there is a new situation at hand, and that what needs to be done may involve actions that would in another context be considered problematic. In comparing Moshoeshoe to Shaka, Knight (1994: 53) makes these interesting points: "At first glance, there are a number of similarities between the careers of Moshoeshoe of the Basotho and his more famous contemporary Shaka of the Zulu. Both were sons of minor chiefs, both achieved some early fame as warriors, both owe their rise to a period of terrible upheaval and both emerged as founding fathers of new nation - states. Yet their personalities had little in common. Shaka was a ruthless warrior who exploited a period of tension to expand his territory by the vigorous use of military force. The resulting Zulu Kingdom was politically highly centralized, with the king himself keeping a tight grip on the reigns of power. Moshoeshoe, on the other hand, was a statesman; a compassionate man who accumulated followers by offering the refuge on his mountain stronghold, and demanding allegiance, rather than submission. His followers regarded him with respect rather than awe".

Any one of the above mentioned achievements would by itself deserve prominent mention in the history of Lesotho. Taken together, they point to an administrative leadership capacity and excellence of Moshoeshoe. It is not the purpose of this paper to demonstrate Moshoeshoe's organizational leadership achievement, which is widely acknowledged and documented (Sanders, 1975; Thompson, 1975). Rather the intent is to look into his character, practices and beliefs to gain understanding of the personal attributes related to the ethical dimensions of his administrative, managerial and leadership style. Whether such attributes are related to achievements, and to what extent, is a subject left for another time. 


\section{Moshoeshoe's Ethics and Attributes of Leadership}

An exhaustive examination of Moshoeshoe's life and leadership career, decisions, personal traits and role-related behaviours may be found in the literature, mostly in biographical style (Sanders, 1975; Thompson, 1975). Discovering Moshoeshoe's administrative philosophy and managerial style is more difficult. That said, however, from observations of credible third parties who worked with him, and inferences drawn from their respective corroboration, much is learned about what is referred to in this essay as his "attributes" i.e. character traits and practices that had something to do with his administrative roles. The analysis will proceed by articulating a set of personal attributes generally recognized in the public administration and leadership literatures as related to ethical leadership, and simultaneously linking these attributes to observations of Moshoeshoe'sbahaviour, practices, reasoning and principles.The set of leadership-related attributes was aggregated from a variety of sources, including scholars and organizational practitioners, among them Gibbon (2002), Collins (2001), Denhardt(1993), Cooper and Wright (1992), Bailey (1965), and Schubert (1960). The attributes so compiled are:

- Personal courage

- Putting the public interest ahead of self or narrow organizational interests

- Integrity and self-discipline

- High ethical standards

- Political/social/economic sensitivity

- Inclusiveness

Each of the above-listed attributes would be discussed below to gain understanding of the personal traits related to the ethical dimensions of Moshoeshoe's leadership style of public management.

\section{Exceptional Courage}

First among the qualities of ethical leadership is courage (Bailey, 1965). Courage is needed to face down pressures based on friendship or popular majorities or expert opinion. There are many examples of Moshoeshoe's courage throughout his career. For instance, as a young warrior, he quickly gained reputation in the way he would allegedly bind and subsequently subdue his enemy. His courageous prowess was pronounced when after circumcision class, his whole age group under his command raided chief Ramonaheng of the Bafokeng, one of the small chiefs then in present-day Lesotho. It was said that the raid was so successful that he returned with so many cattle (Becker, 1969: 23-24; Sanders, 1975: 11-12).

Another example occurred when as a young warrior persuaded the tribal court to forgive a cattle - thief at the expense of his own standing as a warrior and his actions brought into question even his own loyalty to the clan (Becker, 1969: 22). In another instance, with extraordinary skill and courage, he set free Rakotsoane, the cannibal chief and his band that his people clamoured for revenge for eating his grandfather, Peete. With a remarkable lack of 
resentment, he merely observed that it was not customary to disturb the graves of one's ancestors (Sanders, 1975: 56).

Perhaps the most remarkable courage displayed by Moshoeshoe was when he took a strong public stand against the killing of supposed witches (Thompson, 1975:94). Indeed, through courage in battle and decision-making, Moshoeshoe built a new united nation called Basotho at his fortress of Thaba-Bosiu out of the devastation that came to be known as Lifaqane (Gay, Gill \& Hall, 1995: 5).

\section{Putting the public interest before self}

Hart and Hart state "the justification for use of power by public (leadership) is the advancement of the public interest" (1992:91). Moshoeshoe's theory of what constitutes the public interest was grounded in his conviction that' a chief is a chief by the goodwill or grace of the people.' As such, he preferred to rule his people by consensus (and servitude), leading them subtly around to his way of thinking in the Pitso, the tribal gathering where events of national importance are discussed [Knight, 1994: 54-55]. Through mafisa system, Moshoeshoe was able to incorporate many people to form a new nation by accepting mafisa cattle (Eldredge, 1993: 37). Commenting further, Thompson [1975: 211] states, "As the owner of vast wealth in sheep and cattle, he was able to bind people to him by judicious gifts, by lending them livestock on mafisa, and by establishing cattle-posts under reliable followers." Indeed thousands of impoverished commoners and chiefs during the upheaval of the Lifagane benefited handsomely from mafisa system (Gay, Gill \& Hall, 1995).

Moshoeshoe also grew national spirit by skillfully masterminding working parties as a mudus operandi for cultivating his chief's lands for communal consumption. According to Thompson (1975: 175), " he sent working parties to cultivate his chief's lands (Letsema) and enemy fields ( $T$ s'imoea lira), because their produce was consumed not only by the chief's family and personal dependents (refugees) but by all men of the chiefdom at the pitso and in time of war." Thompson (1975: ibid) comments further: He allowed his followers to appeal to the chief's court (Lekhotla) against his own decisions. He contributed cattle when required for general purposes (Sethaba-thaba), such as the payment of compensation and tribute to neighbouring chiefs."

Indeed, Moshoeshoe's selflessness is well recorded in the testimony of his son Sekhonyana; "[He] gained the esteem of the [Basotho]. . . by succouring the distressed and protected them and not keeping recaptured cattle of other clans of the [Basotho] for himself, as he could have done according to custom, but returning them to their owners" Knight, 1994: 63-64]. Through these means, of course, their 'owners' ( who no longer owned them, in fact, merely held them under the Mafisa system) were drawn into his chiefdom (Sanders, 1975: 56).

\section{Integrity and self-discipline}

Moshoeshoe was also renowned for his rock-solid integrity, the third leadership attribute he had in abundance. Looking at the pardoning of the cannibals under Rakotsoane who had eaten his grandfather Peete, Moshoeshoe demonstrated integrity (Du Preez, 2004; Thompson, 1975), for not only did he promised that they could be returned if they helped him with the 
traditional burial ceremony, but afterwards he invited them to join in a feast of thanksgiving. He then proceeded to give chief Rakotsoane a gift of cattle and had him and his cannibals escorted back to their place in sufficing. He could just as easily have proceeded to kill them and bury them "together with old Peete" once the ceremony was finished (Becker, 1969: 74-75).

Moshoeshoe believed that the best type of discipline is self-disciple, developed from within the person and not imposed. His utter devotion to task, a hallmark of his own self-discipline, manifested itself in many ways. When his anger was aroused he could terrify and sometimes even attack his subjects, but usually he was affable and tolerant of human foibles. To illustrate this, Thompson states, "On one occasion a missionary was astonished to see that he took indulgent attitude towards a drunken warrior who abused him in scurrilous terms ... Moshoeshoe himself always abstained from strong beer, wild hemp and even tobacco, declaring 'If I were to drink, I would be talking folly before my people"” (1975:63).

\section{High ethical standards}

Moshoeshoe demanded a high level of ethical conduct from everyone and conducted himself in a manner that set a clear model for others to emulate. He possessed a strong moral code that honored human dignity, honest dealing, and following through on promises, and he was opposed to fraternizing with foreigners. His moral code enabled him to retain the goodwill of people he ruled (Sanders, 1975; Thompson, 1975). As Ellenberger notes, “. . . he had all the (moral) qualities which go to make him (a chief)" (1912: 229). Indeed, Moshoeshoe's notoriety as a benevolent chief emanated from values he possessed.

Corroborating this fact, Ellenberger (1912: 229) comments further: He could see further ahead than most men; and, no matter what checks he encountered, he never lost sight of the end in view. Being one of the most astute men of his race and time, he was quick to realize the practical advantages of a policy of benevolence and mercy, quite a new thing in those wild days, when people were ruled by force and fear. Early in life, too, he perceived the disadvantages of the old system of tribal independence; seeing in it possibilities of abuse of power by a multitude of chiefs with no central overlord, and, more important still, a lack of cohesion in resisting a common foe. He had already conceived the idea of federating all clans and tribes, and establishing a uniform code of law and equity among them, when the national convulsions of Lifaqane came, and afforded him the opportunity of creating a kingdom for himself instead.

Despite his well-developed ethical values, Moshoeshoe was a kind of a person who easily took to extreme anger even on small provocations (Goma, 1960; Motsamai, 1952). Long before becoming a chief, as a young man, he is reported once to have killed five other young men with his knob-stick over some insignificant matter. Fearing that he would suffer the same fade as those whom he has destroyed, Peete, his grandfather, took him to Mohlomi, the psychiatrist for cure. Indeed, the moral development of Moshoeshoe is attributed to Mohlomi's teachings (Mokhehle, 1976). 


\section{Political/social/economic sensitivity}

Lesotho at the time of Moshoeshoe had to ride roughshod over socio-economic and political divisive elements which threatened to plunge the nascent kingdom into chaos [Mothibe, 1989]. These elements were many and varied. They included the violent refugees' political states released by Lifagane, through Shaka military conquests, the fugitive Boers and the British imperial pioneership, coupled with the socio-economic hardships. These elements shook and tested Moshoeshoe's socio-economic and political sensitivity to the unprecedented limits. The manner in which Moshoeshoe excised leadership to create order out of the surrounding chaos point to his political acumen: he must have sensed the pressure of external events pushing inward towards him, and further sensed the limitations of confronting the pressures on their own terms (Ndebele, 2006).

It was in the context of the above-alluded forces of destabilization that Moshoeshoe right from the beginning established an extensive network of diplomatic relations cutting across social, economic and political spheres. Central to these relations was, Mothibe notes, "Moshoeshoe's objective to build by peaceful means a nation with viable territorial base, which enjoyed sovereignty and respect of its neighbours" (1989:4). Corroborating this point, Ndebele (2006: 4) comments further: "He created a junction of sorts where those arriving would owe allegiance to the overarching values of peace and social justice while maintaining their languages and culture. Over time the cultural plurality became, itself a binding attribute. Moshoeshoe was able to prove that diversity can be a binding attribute, in an environment in which it could otherwise be expected to be divisive. This seems a key principle of leadership for Moshoeshoe, and is not an easy one to grasp."

Indeed, Moshoeshoe's superior diplomatic qualities and acumen sparkled brilliantly during his dealing with the Lifagane refugee plunders, namely Zulus, Ngwanes, Ndebeles, Boers, Khoikhoi and British (Sanders, 1979; Thompson, 1979). Whenever possible, he staved off their pillages by offering them tribute for future social, economic and political gains. He tipped the political balance of power and regularized social and economic relations in his favour by becoming a tributary to his friends and foes. There are remarkable stories of how Moshoeshoe dealt with his aggressors i.e. Mzilkazi, the aggressor and Sir George Cathcart, the British Commander who attacked Thaba-Bosiu(mountain by night) and failed. In an unexpected turn of events, when Mzilikazi and Sir George Cathcart retreated from Thaba-Bosiu with a bruised ego after failing to take over the mountain, he sent to them a present of cattle. Commenting on the essence of this particular act of Moshoeshoe, Ndebele (2006:5) says: "The unusual way he dealt with Mzilikazi and other aggressors mirrored his relations with his people. It is likely that Moshoeshoe surmised: the people around me, secured in a protective space, have survived social dislocations. They may easily reproduce in the new environment the culture of aggression engendered by the dislocation they have experienced. That could render vulnerable the safe apace that Lesotho could be, and became. It was not enough to secure the physical space: it was equally vital to create and secure a new psycho-social space through robust law and customs, and participative governance. A new value system was required in which learned bahaviour was turned around." 
Inclusiveness

Thompson (1975) paints the context within which Moshoeshoe exercise leadership thus: "Moshoeshoe had experienced all the crucial changes which had taken place on the South African high veld - from the comparative stability of traditional societies in his youth, through the anarchy of the Lifagane, to the intrusion of French missionaries, Afrikaner farmers, and British officials. More skillfully than any other African confronted with similar problems, he had managed to create a kingdom out of chaos and to steer that kingdom through manifold dangers to what was probably the best destiny that was open to it in the changed world of the late $19^{\text {th }}$ century".

According to Ndebele (2006: 3-4) the above context in which Moshoeshoe exercised leadership raised two fundamental questions: How do you create order out of the surrounding chaos? More urgently, how do you sustain such order? In fact the essence of Moshoeshoe's challenge as a state-maker was how to build and hold his political community together while it was expanding greatly in scale. According to the evidence from a score of commentators (Ndebele, 2006; Du Preez, 2004; Knight, 1994; Mothibe, 1989; Mokhehle, 1976; Sanders 1975, Thompson, 1975; Suzman, 1972; Becker, 1969; Goma, 1960; Motsamai, 1952; Ellenberger, 1912), the key to Moshoeshoe's success may have been his tolerance for democratic and civilian values. In Moshoeshoe's view, such tolerance was essential to bringing cohesion and harmony among various nexus of the kingdom 'accustomed to gradations of authority and autonomy and to ambiguities in the distribution of power' (Thompson, 1975: 175-76).

In a globalized world, diversity in organizations is now a very important aspect of ethical leadership, and Moshoeshoe showed early sensitivity to the dynamic. For example, building on the traditional methods he learnt from his youth, Moshoeshoe attracted and retained the services of able Matona (advisers) representing different interests and points of view (Thompson, 1975: 204). However, Thompson notes, "the Matona(councilors) did not constitute an exclusive councilor body, for Moshoeshoe always felt free to consult anyone he pleased" (Thompson, Ibid). Indeed, plurality and diversity were thus a hallmark of the kingdom since its inception. As Ndebele (2006: 4) notes," Over time the cultural plurality became, itself a binding value (amongst Basotho). Moshoeshoe was able to prove that diversity can be a binding attribute, in an environment in which it could otherwise be expected to be divisive." He became, in Thompson's words, "a master of real politic. His envoys were everywhere - he could well be called the first African exponent of an outward policy and a past master in the art of dialogue ... a political decision was the end product of a prolonged series of discussions. . a an effective decision was one which embodied the consensus of the entire political community" (1975: 207-08).

\section{Moshoeshoe's Respected Personal Traits}

Besides integrity and courage, commentators (Ndebele, 2006; Mothibe, 1989; Suzman, 1972; Thompson, 1957; Sanders, 1975) have noted Moshoeshoe's remarkable capabilities of marked talent for diplomacy, lack of vengefulness and overwhelming conciliatory policy, astuteness and farsightedness, superior military and political talent. For these traits and his 
personality he was greatly admired. According to Suzman, "Moshoeshoe was the ideal chief - physically strong, a man of great personal magnetism. Everyone who met him came away impressed" (1972: 11). Casalis, describing his first encounter in 1833 with Moshoeshoe, wrote, "I felt at once that I had to do with a superior man, trained to think and to command others and above all, himself" (Thompson, 1975).

Sir Andrew Smith, leader of a scientific expedition in 1833, called him kindly, "a man with uncommon insight into human relationships, with a gentle unassuming convivial disposition" (Thompson, Ibid). Arbousset described the chief's gaity and charm thus, "He speaks to everyone without distinction of age or rank. Even more astonishing his memory is so good that he seems to know the name and history of each of his subjects" (Thompson, 1975). Again to quote Suzman, "Moshoeshoe's statesmanship revealed itself in many ways as he responded sagaciously to the challenges which confronted him through his life: from his earliest years when his qualities of leadership first emerged, to his last day when he managed to ensure the continued existence of the nation that he himself had created" (1972: 13). Some or all of these traits may have helped Moshoeshoe to win the hearts and minds of his subjects then. However, there is little on the literature to support a claim that all the traits Moshoeshoe displayed are necessary to ethical leadership.

\section{Moshoeshoe's Moral Shortcomings and Prowess}

A discussion of Moshoeshoe would be void if his encounter with ethics or morality in his life is neglected. Whence, this section attempts below to discuss Moshoeshoe's encounters with ethics or morality is his life.

Moshoeshoe, in his youthful days, days was a wild person (Motsamai, 1952) with a bad temper. He easily took to extreme anger even on small provocations (Guma, 1960). He is reported once to have killed five other young men with his knob-stick over some insignificant matter - demanding unjustifiable respect and recognition from them as their 'chief' (Ellenberger and Mcgregor, 1812). In his old age, when he was found of recollecting his former glories, he is said to have confessed to his son, Molapo that while he was a young man, he had a burning desire to become a chief (Sanders, 1975: 19). His extreme desire for chieftainship thus made him to be a forceful and domineering character, which believed that ordinary people have become chiefs by intimidating, bullying and inspiring others with fear. His actions and professions were, more often than not, always in defiance of his father's orders to the point that he was taken by his grandfather Peete to chief Mohlomi, the psychiatrist for cure.

After meeting his mentor or life coach Mohlomi, Moshoeshoe became a completely changed character. His wisdom, bravery, brightness, intelligence and humanity shined over his past He began to be noted for his many acts of kindness and generosity as well as his advocacy for peace, which formed the basis of his leadership career. Through moral influence and military prowess, he rallied the survivors of Lifagane wars and built a kingdom (Thompson, 1979: vii). He respected the dignity of every single person. He ruled by consultation and consent, and he rarely imposed the death penalty. His was a self-disciplined and integrated personality. $\mathrm{He}$ abstained from drinking alcohol and smoking cannabis, for he declared that they would 
prevent him from making wise decisions. He was a selective innovator, quick to appreciate the advantages of guns, horses, new crops and literary education.

Above all, he was a realist and a patriot. While he accepted much of Christian Doctrine, he had compelling social and political reasons for rejecting several aspects of the teachings presented by the missionaries. To preserve the cohesion of his people he kept on foot in the conservative and traditionalist realm, even while placing the other in the modern and Christian realm. He acquired a deep understanding of the changing power relationships in the southern African state system of his day and, matching his policy to his means, he pursued an active diplomacy.

He resorted to warfare only in self-defense or under the utmost provocation, and when he did so he deployed his forces with great skill. His own mountain stronghold of Thaba-Bosiu (mountain by night) was never captured in his lifetime. He was adept in extracting political advantages from military successes, even when this required great restraint and magnanimity. It was only after he had repeatedly been deceived by British officials that his country had been ravaged by Afrikaner commandos that he himself became devious; and he was nearly eighty years of age by the time he lost control his own more reckless subordinates.

\section{Moshoeshoe - Linking Attributes to Effectiveness}

According to Pops (2006: 181), proof of the efficacy of ethical leadership must necessarily await the aggregation of multiple cases in which the presence of certain attributes is correlated with acknowledged achievement under specific and differing circumstances. The point raised here by Pops is which leadership traits, behaviours and approaches are likely to be critical variables in producing good results. Two studies conducted by Denhardt (1993) and Collins (2001) systematically address the point raised.

First, Denhardt (1993: Vii) examines leader processes, characteristics, and philosophies in evidence in the variety of public programs widely acknowledged as successful. He lists five approaches common to the reputedly exemplary public administrators he interviewed: (1) a commitment to values, (2) concern for serving the public, (3) empowerment and shared leadership, (4) pragmatic incrementalism, and (5) dedication to public service. He deposits that these capture the new style of public management widely accepted as successful.

Second, Collins (2001:73) and his team also identified and studied highly successful corporate executives. The best of them were found to share the following qualities: (1) they channel their ego needs into institutional goals and not into themselves-a process demanding humility plus a strong will, compelling modesty, ferocious resolve, and finally giving credit to factors outside themselves when things go well and accepting personal responsibility when things go poorly.; (2) they possess workmanlike diligence; (3) they usually grow up within the organization; (4) they have the ability to get and keep enough of the right people and to match the best people with the best opportunities; (5) they fight like mad before decisions are made, then accept the need for unity afterwards; (6) their visions give way to realities as these arise; and (7) they are not necessarily charismatic. 
Moshoeshoe's leadership career paints a picture of effectiveness that mostly overlaps but also adds to and occasionally departs from the pictures drawn by Denhardt and Collins. His key leadership values or qualities were: (1) the values of unity and restoration, (2) the values of magnanimity, forgiveness and reconciliation, (3) the values of peace, ubuntu and service, and (4) the values of calculated humility. These values are briefly discussed below:

The Values of Unity and restoration -Moshoeshoe seemed to have a greater ability to assimilate a multiplicity of peoples to his mountain stronghold, Thaba-Bosiui.e. mountain by night (Becker, 1969: 67). He seemed to be able to attract peoples from the most disparate backgrounds and unite them into a nation. Through his diplomacy and fairness, these disparate and often desperate peoples were welded together into people with a common language and allegiance (Gay, Gill \& Hall, 1995: 5). So strong were his values of restoration and unity that enabled him to build a present-day united nation called Lesotho in southern Africa.

The values of magnanimity, forgiveness and reconciliation - Moshoeshoe's gestures of forgiveness, reconciliation and magnanimity are well recorded in Basotho history (Lelimo, 2004; Du Preez, 2004; Sanders, 1975; Becker, 1969). He understood that forgiveness, reconciliation and magnanimity are the keys for his rule. AzarialSekese who had known Moshoeshoe characterized the distinctive qualities of his rule thus: he disposed even-handed justice; he did not retaliate against people who had wronged him; he gave sanctuary and aid to refugees and he was not proud to pay tribute to other rules for diplomatic advantage (Sanders, 1975:215).

The values of peace, Ubuntu and service - Moshoeshoe valued peace and he called peace his sister. His strive for peace led him to do peace offerings of cattle to the armies of his foes, who had suffered defeat from his warriors. Just as strining as his value for peace was also his desire for consensus and willingness to serve his people - arising out of Ubuntu. He was noted for being a generous chief than any of his contemporaries and served his people in this manner more than any other chief of his time (Gay, Gill \& Hall, 1995; Knight, 1994; Eldredge, 1993). He embodied the noble qualities of a chief who served his people and understood that his power depended on the goodwill or grace of the people. Indeed, he is remembered as a man who loved people and one who aptly fulfilled the Sesotho proverb morenakemorenakasechaba i.e. a chief is a chief by the grace of his people.

The value of calculated humility - Not only was Moshoeshoe someone who used the reciprocal arrangement of tribal life to great benefit of himself and his people, but he was also astute when it came to the use of calculated humility with an aggressor who could return again or a superior who could possibly be an aggressor in future. Moshoeshoe was magnanimous in his peace offering of cattle to his foes after suffering defeat from his warriors. This calculated humility as a diplomatic stroke of genius by Moshoeshoe, which allowed his foes to save face and offered peace for the future. Thus his regular tributes to powerful chiefs of his time like Matiwane of the Ngwane and Shaka of the Zulus were seen to be totally congruous with his value of calculated humility (Sanders, 1975; Becker, 1969). 


\section{Ml Macrothink}

These ethical values drawn from Moshoeshoe's 'ideal type' leadership career thus strengthen the judgment of Thompson (1975); Sanders (1975); and Ellenberger (1912) that Moshoeshoe is an ethical leadership exemplar. They also affirm his standing as an exemplar of ethical leadership. They further add force to a summative set of acknowledged traits leading to effective public administration or management.

\section{Conclusions}

Close study of leadership career of Moshoeshoe adds to our understanding of the power of ethical leadership. It does this by focusing attention upon a set of personal attributes and practices that are associated with both sterling moral character and monument achievement, thus producing a near-ideal case that may aid in building theory that links ethical leadership to organizational effectiveness. In the case of Moshoeshoe, there is virtually unanimous agreement on his effectiveness and his possession of certain qualities of mind, heart and practice. Indeed, whatever attributes of personality, virtues and practice he exhibited in his leadership role thus gain special saliency in explaining the complex roots of organizational outcomes.

As a leader Moshoeshoe was beset with seeming ethical dilemmas. Though a man of war his love of peace and justice and his horror of war were conspicuous. Through moral influence as much as military prowess, he rallied survivors, and built a kingdom. Moshoeshoe was a humane man. His was a self-disciplined and integrated personality. Like his contemporary Shaka Zulu he built up a great power by his own ability, but did it without that vast sacrifice of human life, those gigantic crimes which marked the career of the Zulu Chief. Unlike Shaka, he respected the dignity of every person, he ruled by consultation and consent, and he rarely imposed the death penalty.

As a human being Moshoeshoe had his own share of faults consisting chiefly of the cunning order that baffled friends and foes alike. In 1852, befooled by the myth of British "Protection", he put his neck into the British noose for all his sagacity. This time around, his skill and cunning could not extricate him from the consequences of that initial error. But, notwithstanding all the faults with which he may justly be reproached, he nonetheless remains, a personality of the first order. He had one aim: to keep his people together, to preserve their independence in the face of enemies who panted to possess their land and reduce them to servitude. It is only when this is understood that his inconsistencies, his finesse and diplomacies can be comprehended.Indeed, Moshoeshoe was truly "a man for all seasons." Yet, at his core, he was confident of his role and abilities, comfortable with and consistent in his moral behaviour and rock solid in his purpose, which was to be a great chief. He was indeed the ethical leadership fundi of his time in the nineteenth century southern Africa.

\section{References:}

Bailey, S. K. 1965. "The Relationship between Ethics and Public Service" In Public Administrationand Democracy: Essays in Honor of Paul Appleby, edited by R. C. Martin. Syracuse, N.Y.: Syracuse University Press, pp. 283-298. 


\section{Macrothink}

Journal of Public Administration and Governance ISSN 2161-7104 2015, Vol. 5, No. 3

Becker, P, 1969, Hill of Destiny: the life and times of Moshoesh founder of the Basotho Nation, London: Longman.

Collins, J. 2001. Good to Great. New York: Harper Collins.

Cooper, T. L., and Wright, N. D. 1992. Exemplary Public Administrators: Character and Leadership in Government. San Francisco: Jossey-Bass.

Denhardt, R. B. 1993. The Pursuit of Significance: Strategies for Managerial Success in Public Organizations. Prospect Heights, Ill.: Waveland Press.

Du Preez, M. 2004. Of Warriors, Lovers and Prophets Unusual Stories from South Africa's Past. Cape Town: Zebra Press.

Eldredge, E. 1993.A South African Kingdom - The Pursuit of Security in the C19 Lesotho, Cambridge: Cambridge University Press.

Ellenberger, D.F and Macgregor, J.C. 1912. History of Basuto - Ancient and Modern, London: Caxton Publishing Company.

Ellenberger, D.F. 1972. History of Basuto: Ancient and Modern, Morija, Morija Printing Works.

Gay. J., Gill. D and Hall, D. (eds). 1995. Lesotho's Long Journey: Hard Choices at the Crossroads. Maseru: Sechaba Consultants.

Gibbon, Peter H. 2002. A Call to Heroism. New York: Atlantic Monthly Press.

Guma, S.M. 1960. MorenaMohlomiMor'aMonyane. Pietermaritzburg: Shuter\& Shooter.

Hart, D. K., and Hart, D. W. 1992. "George C. Marshall and J. Edgar Hoover: Noblesse Oblige and Self-Serving Power." In Exemplary Public Administrators: Character and Leadership in Government, edited by Terry L. Cooper and N. Dale Wright. San Francisco: Jossey-Bass, pp.80-102.

Knight, I.J. 1994.Warrior Chiefs of Southern Africa, UK: Firebird Book.

[MacIntyre, A. 1984.After Virtue: A Study in Moral Theory. 2d ed. Notre Dame, Ind.: University of Notre Dame Press.

Mokhehle, N. (ed.), 1976. Moshoeshoe 1 Profile Se-Moshoeshoe. Maseru: Mmoho Publications.

Motsamai, E. 1952.MorenaMoshoeshoemor'aMokhachane.Pietermaritzburg: Shuter\& Shooter.

Ndebele, N., 2006, Perspectives of Leadership Challenges in South Africa - Inaugural King Moshoeshoe Memorial Lecture, Bloemfontein: University of the Free State.

Sanders, P., 1975, Moshoeshoe - Chief of the Sotho, London: Heinemann. 


\section{Macrothink}

Journal of Public Administration and Governance ISSN 2161-7104 2015, Vol. 5, No. 3

Schubert, Glendon A. 1960. The Public Interest: A Critique of the Theory of a Political Concept. Glencoe, Ill.: Free Press.

Suzman, H. 1972.Moshoeshoe, the statesman. Inauguration of the Moshoeshoe memorial lecture series. Maseru: Government Printer.

Thompson, L., 1975. Survival in Two Worlds: Moshoeshoe of Lesotho 1786-1870. Oxford: Oxford University Press. 